\title{
Vascular endothelial growth factor and epithelial cell adhesion molecule immunoexpression in enzootic nasal adenocarcinoma of goats
}

\author{
Nilay SERPIN ${ }^{1, a}$, Özlem ÖZMEN \\ ${ }^{1}$ Burdur Mehmet Akif Ersoy University, Faculty of Veterinary Medicine, Department of Pathology, 15030, Burdur, Turkey. \\ ${ }^{\mathrm{a} O R C I D: 0000-0002-2535-2315 ; ~}{ }^{\mathrm{b} O R C I D: 0000-0002-1835-1082}$ \\ Corresponding author: ozlemozmen@mehmetakif.edu.tr \\ Received date: 05.06.2019- Accepted date: 20.09.2019
}

\begin{abstract}
Enzootic nasal adenocarcinoma (ENA) is a contagious and viral disease in sheep and goats. The disease leads to the death of the affected animals and causes economic losses in infected small ruminant flocks. Epithelial cell adhesion molecule (EpCAM) is a newly discovered tumor antigen, commonly expressed by several tumors occurring in humans. Vascular endothelial growth factor (VEGF) is a signal protein produced by cells that stimulate the formation of blood vessels and plays an important role in angiogenesis, essential for tumor development. In this study, ENA originating from the nasal mucosa is detected on histopathological and cytopathological examinations, with transmission electron microscopy confirming viral particles in the tumoral cells. The aim of this study was to examine VEGF and EpCAM immunoexpressions using streptavidin-biotin complex immunoperoxidase technique in 24 naturally ENA-affected goats. Sneezing, dyspnea, seromucous or purulent nasal discharge, exophthalmos, and weight loss were commonly observed clinical symptoms. The tumors located in the nasal cavity were generally unilateral and were bilateral in only two cases. Cytological examination of the tumoral masses revealed uniform epithelial cell clusters and abundant inflammatory reaction. On histopathological examination, tubular, papillary, or mixed types of ENA were diagnosed. On ultrastructural examination, intracytoplasmic, spherical, retrovirus-like particles were demonstrated. Immunohistochemically, strong positive reactions were reported for both EpCAM and VEGF in the cytoplasm of the tumor cells. Thus, this study showed that EpCAM and VEGF may have an important role in ENA pathogenesis.
\end{abstract}

Keywords: Clinicopathology, enzootic nasal adenocarcinoma, pathogenesis, VEGF, EpCAM.

\section{Keçi enzootik nazal adenokarsinomlarında vasküler endoteliyal büyüme faktörü ve epiteliyal hücre adezyon molekülü immunoreaksiyonları}

Özet: Enzootik nazal adenokarsinom (ENA) koyun ve keçilerin viral ve bulaşıcı bir hastalığıdır. Hastalık etkilenen hayvanların ölümüne yol açarak enfekte küçük ruminant sürülerinde ekonomik kayıplara neden olur. Epiteliyal hücre adezyon molekülü (EpHAM), insanların birçok tümörü tarafından sentezlenen yeni keşfedilmiş bir tümör antijenidir. Vasküler endoteliyal büyüme faktörü (VEBF), hücreler tarafından üretilen kan damarlarının oluşumunu uyaran, tümör gelişimi için gerekli olan ve anjiyogenezde önemli rol oynayan bir sinyal proteinidir. Bu çalışmada, nazal mukozadan kaynaklanan ENA'da, histopatolojik ve sitopatolojik incelemelerde yapıldı ve viral partiküller tümör hücrelerinde transmisyon elektron mikroskobu ile saptandı. Bu çalışmanın amacı ENA ile doğal enfekte 24 keçide klinik, patolojik, sitolojik, elektron mikroskobik bulgular ile VEBF ve EpHAM ekspresyonlarının immunohistokimyasal olarak streptoavidin-biotin kompleks metoduyla incelenmesidir. Olguların birçoğunda klinik olarak hapşırma, solunum güçlüğü, serömüköz veya purulent burun akıntısı, ekzoftalmus ve kilo kaybı bulguları gözlendi. Tümörler burun boşluğunda genellikle tek taraflı, sadece iki olguda çift taraflı olarak yerleşmişti. Tümöral kitlelerin sitolojik incelemesinde genellikle üniform şekilli epitel hücre kümeleri ve belirgin yangısal reaksiyon dikkati çekti. Histopatolojik incelemede tubuler, papiller veya karışı tipte görünümler saptandı. Elektron mikroskobik incelemede yuvarlak şekilli intrasitoplazmik Retrovirus benzeri partiküller gözlendi. Immunohistokimyasal olarak tümör hücrelerinin sitoplazmalarında hem EpHAM hem de VEGF yönünden güçlü pozitif reaksiyon saptandı. Bu çalışma EpHAM ve VEBF'nin ENA patojenezinde önemli bir rol oynayabileceğini gösterdi.

Anahtar sözcükler: Enzootik nazal adenokarsinom, klinikopatoloji, patojenez, VEBF, EpHAM.

\section{Introduction}

Enzootic nasal adenocarcinoma (ENA) is an economically important, contagious, viral, and progressive disease, characterized by neoplastic transformation originating from the ethmoid mucosa of sheep and goats $(3,12,13,29-31)$. Enzootic nasal 
adenocarcinoma virus (ENAV), a retrovirus, is known as a potential agent. This tumor is naturally occurring worldwide and has been reported in several countries, including Turkey $(2,3,12,13,30-32)$. Clinically, the tumor is characterized by chronic and progressive respiratory symptoms. Grossly, the tumor can be localized unilaterally or bilaterally in the nasal cavity $(3,11,30,31)$. Cytological examination of the tumoral masses reveals uniform epithelial cells and abundant inflammatory reaction, the main characteristic of the tumor (34). The tumoral cells are generally uniform with no cellular atypia, and tubular, papillary, acinar, and mixed patterns may be evident on microscopical examination. Genetic, breed, and sex predispositions have not been reported in any published study. ENA leads to death in the affected animals; however, mortality rate may vary from flock to flock (30-32).

To reach a definitive diagnosis, cytological, histopathological, and ultrastructural examinations are necessary $(11,29-31)$. Transmission electron microscopy (TEM) analysis is an important technique to distinguish ENA from other nasal tumors (30).

Vascular endothelial growth factor (VEGF) is a heparin-binding growth factor in a homodimeric glycoprotein construction, specific to vascular endothelial cells $(9,18,36)$. It plays an important role in vasculogenesis, angiogenesis, differentiation of endothelial cells, inflammation, and tumor formation, proliferation, and migration $(6,8,9,17,27)$. VEGF, proven to be overexpressed in several types of cancers, as a key factor in the regulation of angiogenesis, has been shown to provide the activation of endothelial cells as well as the most specific mitogens known for the endothelial cells $(7,9,27)$.

Epithelial cell adhesion molecule (EpCAM) is a surface molecule that is highly expressed in different carcinomas (23, 29). EpCAM acts as a calciumindependent homotypic cell adhesion molecule intracellularly and exhibits adhesion at the stages of cellcell adhesion, cell aggregation, and inhibition of cell spreading $(5,20)$. EpCAM and VEGF expressions are not completely defined in animal tumors, and there is no report in ENA. The aim of this study was to examine VEGF and EpCAM expressions in the neoplastic cells and show their possible roles in the pathogenesis of ENA in naturally-infected goats.

\section{Material and Methods}

Tissue samples: In this study, tissues were collected from 24 goats, sent for routine diagnosis to the Department of Pathology, Veterinary Faculty, Burdur Mehmet Akif Ersoy University, from Denizli, Burdur, Isparta, and Antalya, between 2010 and 2015. Normal nasal tissue collected from five goats without ENA sent for routine necropsy were evaluated as controls.

Cytological examination: For cytological examination, touch impression smears were prepared from the fresh tumor tissue during necropsy. The slides were dried in air stream, fixed in methyl alcohol, stained with Giemsa method (Giemsa Stain, Catalog no: 1.09204.0500; Merck Millipore, Darmstadt, Germany), and then examined microscopically.

Histopathological examination: For histopathological studies, tumor samples were fixed in $10 \%$ neutral buffered formalin. The samples were then routinely processed in an automatic tissue processor equipment (Leica ASP300S, Wetzlar, Germany) and embedded in paraffin wax. Tissue sections were cut into $5-\mu \mathrm{m}$-thickness by a rotary microtome (Leica RM2155, Leica Microsystems, Wetzlar, Germany). The sections were stained with hematoxylin-eosin stain (HE), mounted with a coverslip and mounting medium, and examined under a light microscope (24).

Immunohistochemistry: The routine streptavidinbiotin peroxidase complex method was used for the detection of VEGF [Anti-VEGF antibody ( $V G-1)$ (ab1316)] and EpCAM [Anti-EpCAM (ab71916) antibody]. For the immunohistochemical examination, sections were routinely processed according to the manufacturer's instructions. Expose Mouse and Rabbit Specific HRP/DAB detection IHC Kit (ab80436) was used as a secondary antibody. Primary antibodies were omitted for negative controls. All primary serums and secondary antibodies were purchased from Abcam (Cambridge, $\mathrm{UK}$ ), and the primary antibodies were used in $1 / 100$ dilution.

Electron microscopy: Samples were also processed for TEM analysis. They were fixed in $2.2 \%$ glutaraldehyde and post-fixed in $1 \%$ osmium tetroxide $\left(\mathrm{OsO}_{4}\right)$ prepared in $0.1 \mathrm{M}$ phosphate buffer solution. Then, the tumor samples were dehydrated in a graded series of alcohol and embedded in Araldite CY212. Ultrathin sections were taken from plastic blocks and stained with uranyl acetate/lead citrate.

\section{Results}

Chronic and progressive symptoms were characteristic in the anamnesis. Clinically, mostly purulent or seromucous nasal discharge, dyspnea, snoring, coughing, sneezing, mouth breathing, and less frequently, exophthalmos, and deformations in the skull bones were noted. Findings, such as lacrimation, conjunctivitis, facial asymmetry, and in some goats, head shaking were also detected. Rarely, depigmentation and alopecia were observed around the nostrils due to chronic nasal discharge. Anorexia and cachexia were commonly found in the infected animals. At necropsy, soft to hard tumoral 
masses were observed in the nasal cavity (Figure 1). Variable sized tumors were located unilaterally or bilaterally in the ethmoidal region of the nasal cavity in all the animals. The tissues were irregularly structured as pinkish-white polypoid masses (1-2.5 cm in length), sessile (0.5-3 cm in diameter), and covered with seromucous exudate. In only two cases, invasion into the sinus frontalis was observed; however, lymph nodes or internal organ metastases were not detected.

Examination of cytological preparations revealed that the tumoral epithelial cells were generally collected in groups. The cells had marked vesicular nuclei and pale cytoplasm (Figure 2). Cytological examination revealed marked inflammatory reaction characterized by numerous lymphocytes and neutrophils.
Histopathologically, similar and characteristic findings were detected in all cases with ENA. All tumor types (tubular, papillary, and mixed), were observed in our cases. In this study, 9 tubular, 10 papillary, and 5 mixed tumor types were diagnosed. The tumor cells were mostly uniform and cubic, and the nucleus was oval to round and hyperchromatic (Figure 3). Mitotic figures were rarely seen; however, in some cases, pleomorphic cells were identified. In nine of our cases, abundant lymphocyte, plasma cell, and macrophage infiltration was observed.

Immunohistochemistry demonstrated increased VEGF and EpCAM expressions in the tumoral cells compared with those in the normal tissue. It was noticed that the EpCAM activity was high in most of the tumor cells and weak to moderate immunoreaction was seen in some of the tumor cases (Figure 4).
Figure 1. Gross appearance of the tumoral masses (arrows) that completely filled the nasal cavity in a goat.
Figure 2. Cytology of the tumoral cells, irregular, grouped cuboid cells (arrows), Giemsa stain, Bar: $50 \mu \mathrm{m}$.
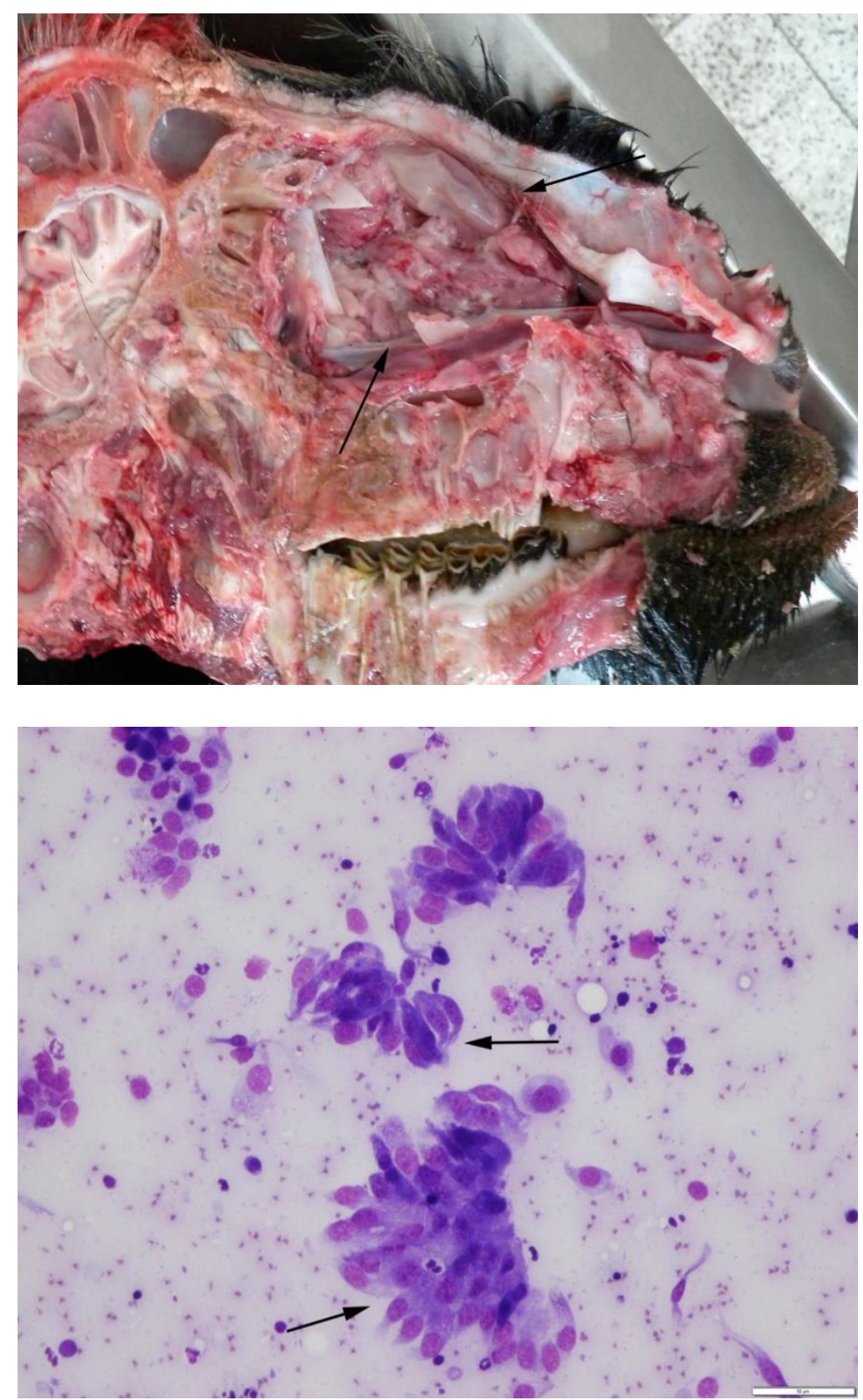


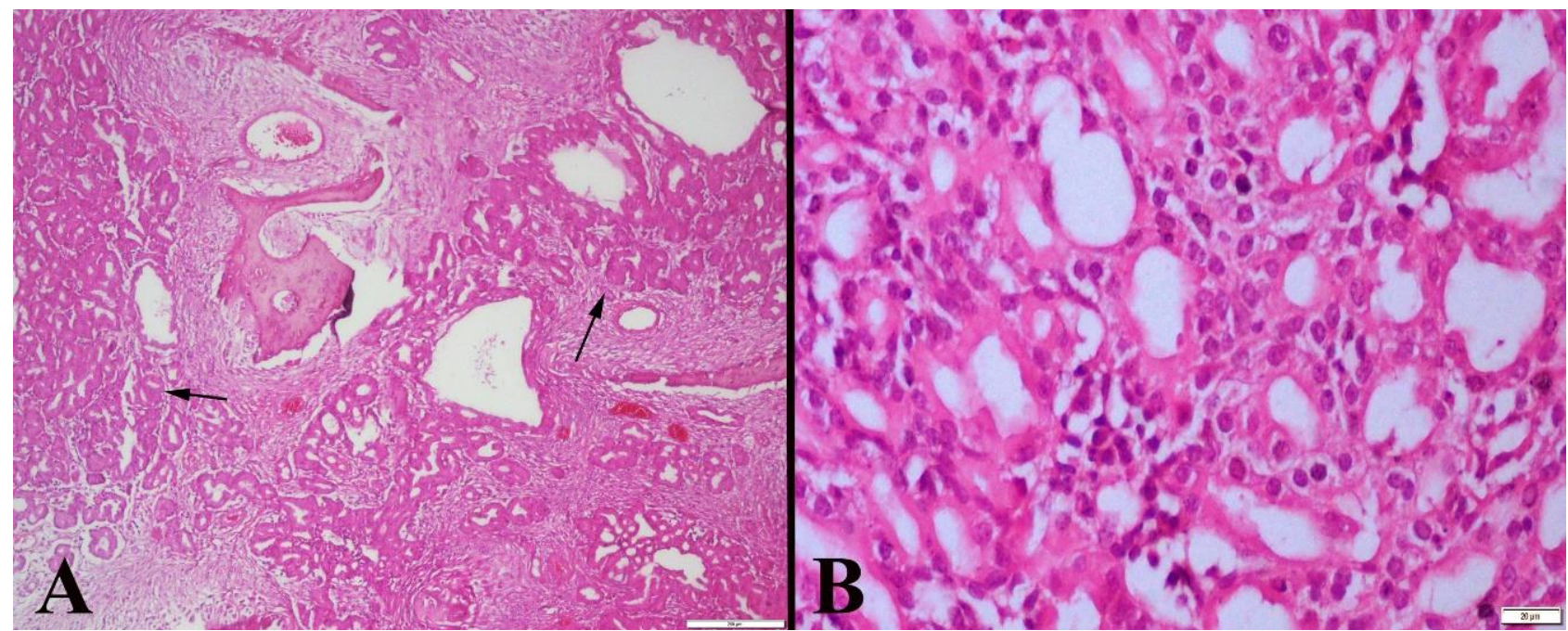

Figure 3. A. Histopathology of the tumoral masses, increase in nasal glands (arrows), H\&E, Bar: $200 \mu \mathrm{m}$, B. Higher magnification of the tumoral cells, H\&E, Bar: $20 \mu \mathrm{m}$.

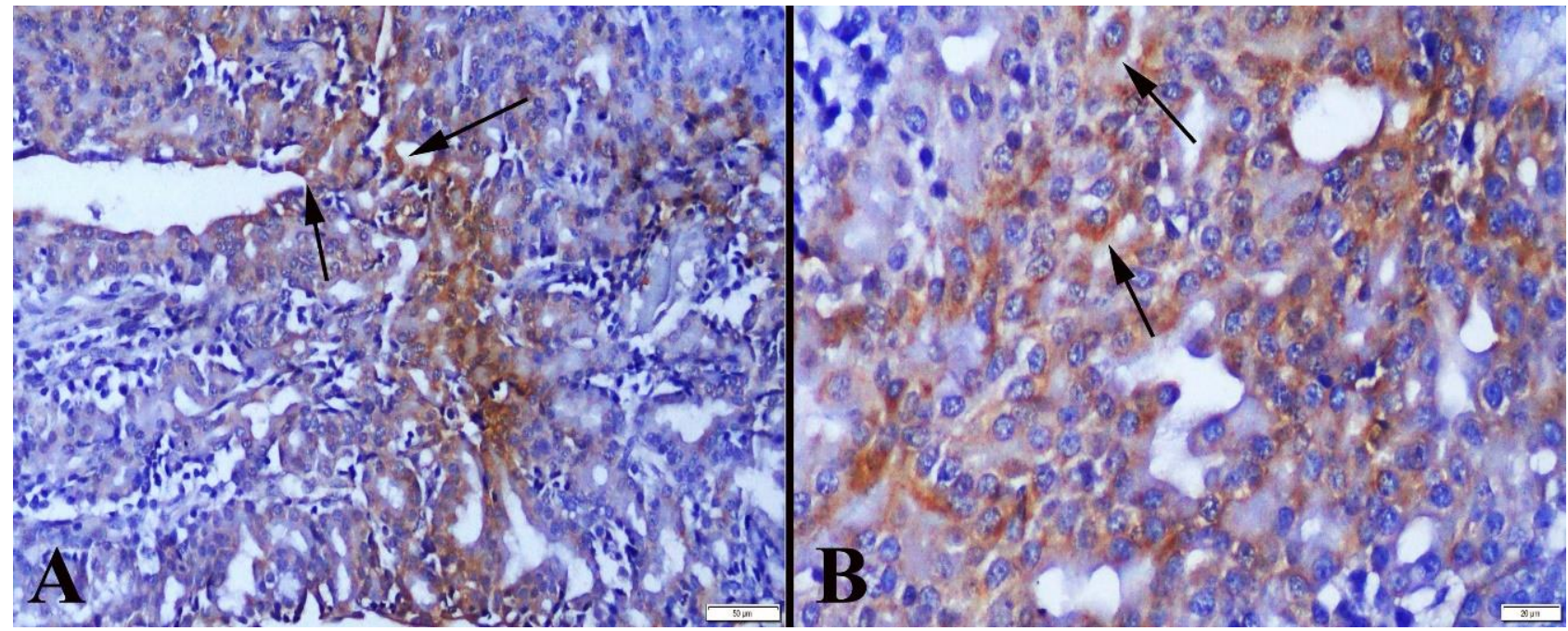

Figure 4. A. Increased EpCAM immunoreaction of the tumoral cells (arrows), Streptavidin-biotin-peroxidase complex method, Bar: $200 \mu \mathrm{m}$, B. Higher magnification of the EpCAM expressed cells (arrows), Streptavidin-biotin-peroxidase complex method, Bar: 20 $\mu \mathrm{m}$.

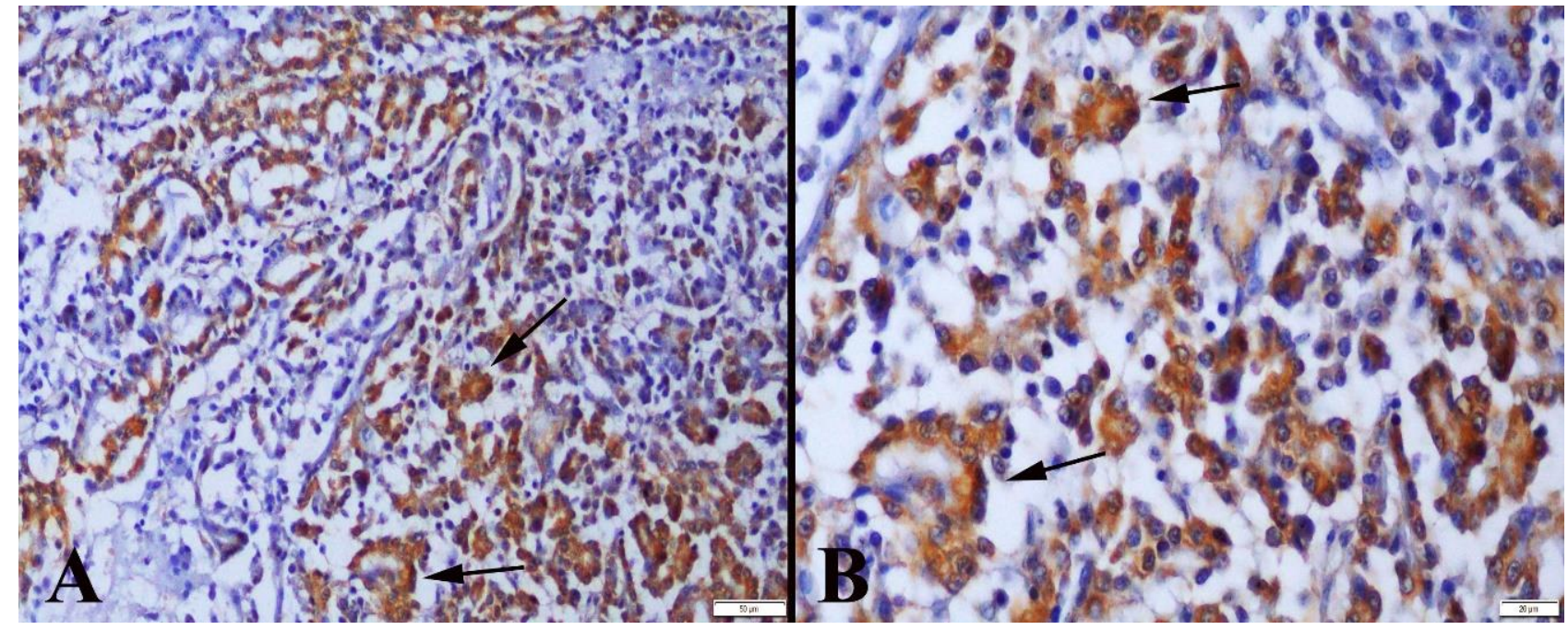

Figure 5. A. Increased VEGF activity in the tumoral cells (arrows), Streptavidin-biotin-peroxidase complex method, Bar: $100 \mu \mathrm{m}, \mathbf{B}$. Higher magnification of the VEGF immune-positive cells, Streptavidin-biotin-peroxidase complex method, Bar: $20 \mu \mathrm{m}$. 
Figure 6. Ultrastructural appearance of the tumoral mass, retroviral particles (arrows) in the cytoplasm of the cells.

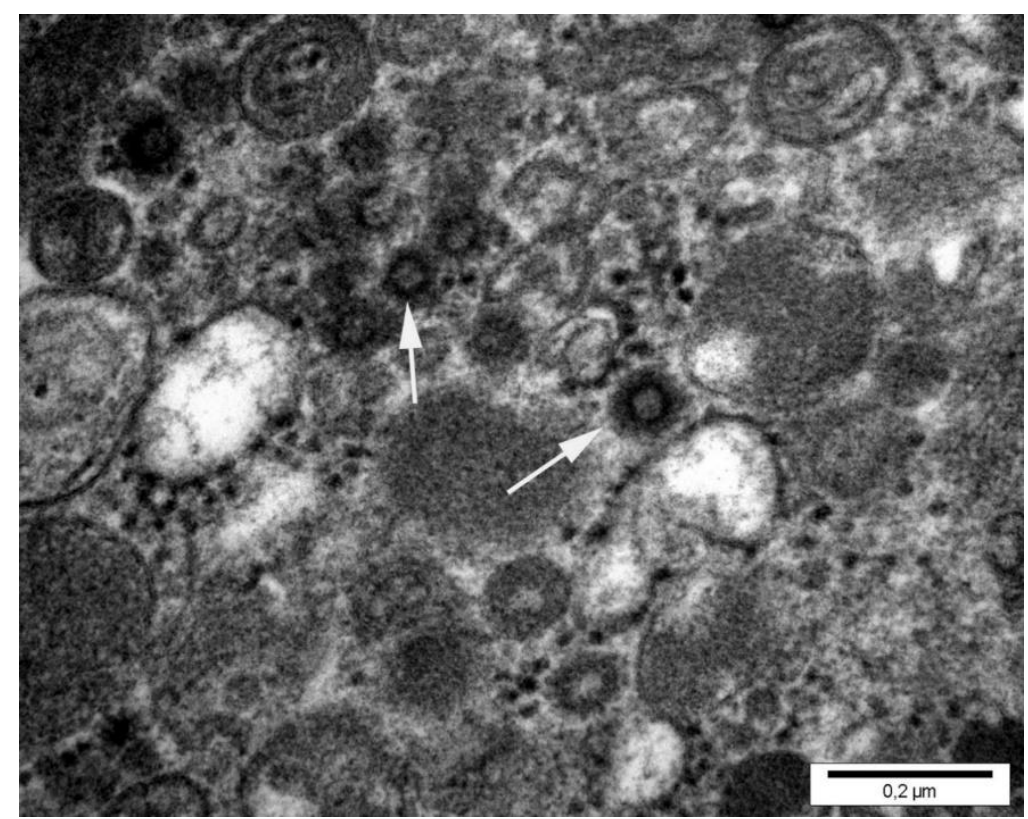

In this study, no correlation between EpCAM expression and the subtypes of tumors was found. EpCAM reaction was generally determined in the cytoplasm near the cell membrane. No or slight EpCAM expression was evident in the normal cells. Similar findings were seen with VEGF immunoreactions and the expression increased in the tumoral cells (Figure 5). In this study, increased EpCAM and VEGF immunoreactions were observed in both the tumoral and some interstitial cells.

In electron microscopic examination, in the cytoplasm of the neoplastic cells, numerous electron opaque and round to oval secretory granules surrounded by a membrane, ranging from 0.2 to $1 \mu \mathrm{m}$ in diameter, were observed. Ultrastructurally, intracytoplasmic spherical retrovirus-like particles $70-90 \mathrm{~nm}$ in diameter, were demonstrated (Figure 6).

\section{Discussion and Conclusion}

ENA was first reported in Turkey in 2010 and became an endemic problem in the Burdur province (2, 3, 30-32). Because of the chronic behavior and tumoral masses located in the nasal cavities, the diagnosis of the disease is generally difficult, and an exact incidence is unknown in the goats in Turkey. Another reason for wrong diagnosis is related to a sporadic behavior and few animal losses due to the disease in a short time. However, the illness can cause an important economic loss over years.

Cytological and histopathological examinations are important for the evaluation of the malignancy. However, it is more important to detect the viral particles in the tumoral cells for a definitive diagnosis of ENA $(30,31)$. To examine the presence of the viral particles, TEM analysis of the tumor samples was performed in this study, and retroviral particles were demonstrated in the cytoplasm of the cells.

EpCAM, a type 1 transmembrane protein, is an epithelial adhesion molecule localized at the basolateral edge of epithelial cells. Studies have shown that EpCAM has an important role in cell interaction and proliferation. EpCAM is highly expressed in human cancer cells, such as those of colorectal, breast, stomach, prostate, ovarian, and lung cancers. It is the first discovered human tumorassociated protein that can be identified with monoclonal antibodies (4). EpCAM expression has been associated with poor prognosis in some types of cancers and good prognosis in other types of cancers. While EpCAM expressions in primary breast cancer are associated with decreased survival, in patients with colorectal cancer its associated with increased survival (25). In renal cell carcinoma (chromophobe and collecting duct origin), EpCAM was found to be an important prognostic marker (19). In vitro and in vivo, EpCAM expression has been associated with the spread of breast cancer to surrounding tissues (10). In accordance with the literature, this study showed that EpCAM activity increased in the ENA cells, and this protein may play an important role in the ENA pathogenesis.

VEGF is a heparin-binding glycoprotein, synthesized by numerous cells, such as tumoral, smooth muscle, and endothelial cells $(16,28)$. It is the most important angiogenic factor and commonly expressed in cancers, such as those of the lung and colon $(9,18)$. Although there are several studies on the expression of VEGF in most types of human cancers, its role in pathogenesis has not been completely understood $(7,26$, 33). In our study, VEGF immunoreaction was found to 
increase in ENA, and this increase was thought to be related to the possible role of VEGF in tumorigenesis.

Head, neck, cervix, colon, and small-cell lung cancers markedly express VEGF (14). VEGF is reported to affect survival in cases of local and locally invasive colorectal cancers, according to a multivariate analysis (21). Because our study was performed on dead animal materials, there was no link between VEGF and the clinical prognosis.

In solid tumors, tumor growth, invasion, and metastatic ability are found to be significantly correlated with the VEGF levels. It has been suggested that increased levels of VEGF in most of the solid tumors, such as those of the breast, lung, prostate, colorectal, bile duct, and liver, may be associated with poor prognosis (1). In another study, they found a correlation between improvement in human mammary tumors and tumor VEGF expression (18). In a similar study, they found that VEGF expression enhances the angiogenic activity (22). In one study, VEGF expression in patients with breast cancer was found to be a malignancy determining factor $(34,35)$. In another study, increased VEGF expression was reported in tumorassociated samples with significant lymph node involvement (15).

It is not practical to examine the duration of disease or predict prognosis and survival in farm animals. The main purpose is the early detection of chronic and contagious diseases such as ENA and the removal of the patient from the flock. The present study shows that EpCAM and VEGF may be important molecules that can serve this purpose in suspect surveillance. ENAs in sheep and goats are invasive, low metastatic tumoral diseases, originating from ethmoidal turbinate, with increased prevalence all over the world. In this study, histopathological and immunohistochemical studies were performed on 24 tumor samples, previously diagnosed as ENA. Increased VEGF and EpCAM expressions were observed in the ENA tissues.

The incidence of ENA is increasing among goat flocks. This endemic problem has been threatening the economy indirectly, day by day, in the Mediterranean region including Burdur province and other provinces, due to bad prognosis in goats. These selected markers may facilitate to better understand the malignant behavior of ENA.

To the best of the authors' knowledge, expressions of VEGF and EpCAM markers have not been previously used in determining prognosis of the tumors. Moreover, electron microscopy as well as the methods used in this study provides an additional value in diagnosis, because retroviral particles could not be demonstrated in every previous study. EpCAM, mentioned as a new therapeutic target in human tumors, may be useful for the treatments and vaccinations against retrovirus-induced tumoral progress or the management of ENA.

\section{Acknowledgements}

This study was supported by the Burdur Mehmet Akif Ersoy University Scientific Projects Commission (Project number: 0311-YL-16).

\section{Conflict of Interest}

The authors declared that there is no conflict of interest.

\section{References}

1. Akbulut H, Altuntas F (2002): Prognostic role of serum vascular endothelial growth factor and nitric oxide in patients with colorectal carcinoma. Cytokine, 20, 184-190.

2. Aydogan A, Haligur M, Ozmen O (2013): Expressions of caspase-3, caspase-7, caspase-9 and cytokeratin AE1/AE3 in goats with enzootic nasal adenocarcinoma: an immunohistochemical study. Vet Med, 58, 417-421.

3. Aydogan A, Ozmen O (2016): Expression of nectin-4 as a potential biomarker in enzootic, nasal adenocarcinoma of goats. Acta Vet Hung, 64, 71-77.

4. Baeuerle PA, Gires O (2007): $\operatorname{EpCAM}$ (CD326) finding its role in cancer. $\mathrm{Br} \mathrm{J}$ Cancer, 96, 417-423.

5. Basak S, Speicher D, Eck S, et al (1998): Colorectal carcinoma invasion inhibition by CO17-1A/GA733 antigen and its murine homologue. J Natl Cancer I, 90, 691-697.

6. Bikfalvi A (2004): Recent developments in the inhibition of angiogenesis: examples from studies on platelet factor-4 and the VEGF/VEGFR system. Biochem Pharmacol, 68, 1017-1021.

7. Broll R, Erdmann H, Duchrow M, et al (2001): Vascular endothelial growth factor (VEGF)- a valuable serum tumour marker in patients with colorectal cancer? Eur J Surg Oncol, 27, 37-42.

8. Bruns CJ, Liu W, Davis DW, et al (2000): Vascular endothelial growth factor is an in vivo survival factor for tumor endothelium in a murine model of colorectal carcinoma liver metastases. Cancer, 89, 488-499.

9. Carmeliet P (2005): VEGF as a key mediator of angiogenesis in cancer. Oncology, 69, 4-10.

10. Cimino A, Halushka M, Illei P, et al (2010): Epithelial cell adhesion molecule (EpCAM) is overexpressed in breast cancer metastases. Breast Cancer Res Treat, 123, 701-708.

11. Cousens C, Minguijon E, Dalziel RG, et al (1999): Complete sequence of enzootic nasal tumor virus, a retrovirus associated with transmissible intranasal tumors of sheep. J Virol, 73, 3986-3993.

12. De Las Heras M, Ortin A, Cousens C, et al (2003): Enzootic nasal adenocarcinoma of sheep and goats. Curr Top Microbiol Immunol, 275, 201-223.

13. Duncan JR, Tyler DE, Van Der Mataten MJ, et al (1967): Enzootic nasal adenocarcinoma in sheep. JAVMA, 151, $732-734$.

14. Dunst J, Becker A, Lautenschlager C (2002): Anemia and elevated systemic levels of vascular endothelial growth factor (VEGF). Strahlenther Onkol, 178, 436-441. 
15. Falkman J, Watson K, Ingber D, et al (1989): Induction of angiogenesis during the transition from hyperplasia to neoplasia. Nature, 339, 58-61.

16. Ferrara N, Gerber HP, Lecouter J (2003): The biology of VEGF and its receptors. Nat Med, 9, 669-676.

17. Gasparini G, Harris AL (1995): Clinical importance of the determination of tumor angiogenesis in breast carcinoma: Much more than a new prognostic tool. J Clin Oncol, 13, 7652-7682.

18. Goel HL, Mercurio AM (2013): VEGF targets the tumour cell. Nat Rev Cancer, 13, 871-882.

19. Guinan P, Saffrin R, Stuhldreher D, et al (1995): Renal cell carcinoma: comparison of the TNM and Robson stage groupings. J Surg Oncol, 59,186-189.

20. Huang L, Yang Y, Yang F, et al (2018): Functions of EpCAM in physiological processes and diseases (Review). Int J Mol Med, 42, 1771-1785.

21. Kwon KA, Kim SH, Oh SY (2010): Clinical significance of preoperative serum vascular endothelial growth factor, interleukin-6, and C-reative protein level in colorectal cancer. BMC Cancer, 14, 203.

22. Lee JS, Kim HS, Jung JJ (2002): Expression of vascular endothelial growth factor in invasive ductal carcinoma of the breast and the relation to angiogenesis and p53 and HER-2/neu protein expression. Appl Immunohistochem Mol Morphol, 10, 289-295.

23. Lee SJ, Chung KY, Kwon JE, et al. (2018): Expression of EPCAM in adenoid cystic carcinoma. Pathology, 50737 741.

24. Luna GL (1968): Manual of histologic staining methods of the armed forces institute of pathology. McGraw Hill Book Co. New York.

25. Maetzel D, Denzel S, Mack B (2009): Nuclear signalling by tumour-associated antigen EpCAM. Nat Cell Biol, 11,162-171.

26. Mall JW, Schwenk W, Philipp AW et al (2002): Serum vascular endothelial growth factor levels correlate better with tumour stage in small cell lung cancer than albumin, neuronspecific enolase or lactate dehydrogenase. Respirology, 7, 99-102.

27. Mercurio AM (2019): VEGF/neuropilin signaling in cancer stem cells. Int J Mol Sci, 20, 490.

28. Neufeld G, Cohen T, Gengrinovitch S, et al (1999): Vascular endothelial growth factor (VEGF) and its receptors. FASEB J, 13, 9-22.

29. Osta WA, Chen Y, Mikhitarian K, et al (2004): EpCAM is overexpressed in breast cancer and is a potential target for breast cancer gene therapy EpCAM is overexpressed in breast cancer and is a potential target for breast cancer gene therapy. Cancer Res, 16, 5818-5824.

30. Ozmen O, Sahinduran S, Haligur M, et al (2010): Clinical, pathological, immunohistochemical and ultrastructural observations on Enzootic Nasal Adenocarcinoma in five goats. Kafkas Univ Vet Fak Derg, 16, 633-639.

31. Ozmen O, Serpin N (2016): First case of Enzootic Nasal Adenocarcinoma (ENA) in a sheep in Turkey. MAE Vet Fak Derg, 1, 87-90.

32. Sahinduran S, Ozmen O, Kıyıcı R (2018): Determination of telomerase enzyme level in Enzootic Intranasal Tumors of goats. Kafkas Univ Vet Fak Derg, 24, 583-588.

33. Salven P, Orpana A, Joensuu H (1999): Leukocytes and platelets of patients with cancer contain high levels of vascular endothelial growth factor. Clin Cancer Res, 5, 487-491.

34. Serpin N, Ozmen O (2016): Koyun ve keçilerde Enzootik Nazal Adenokarsinom'da (ENA) patolojik incelemeler. MAE Vet Fak Derg, 1, 21-28.

35. Toi M, Hoshiva S, Takayanagi T, et al (1994): Association of vascular endothelial growth factor expression with tumor angiogenesis and with early release in primary breast cancer. Jpn J Cancer Res, 85, 1045-1049.

36. Vincenti V, Cassano C, Rocchi M (1996): Assignment of the vascular endothelial growth factor gene to human chromosome 6p21.3. Circulation, 93, 1493-1495. 